\title{
Communism + transnational: the rediscovered equation of internationalism in the Comintern years
}

Sabine Dullin and Brigitte Studer

A fter October 1917, communism was embodied in an International that was organised by and centred on Moscow. This was known as the Third International, the Communist International or the Comintern, which existed from 1919 to 1943. Communism also spawned a new internationalism which connected people around causes from Harlem to Moscow, Hamburg to Buenos Aires, Marseille to Durban, London to Shanghai; it gave rise to global moments of protest and struggle, and myriad diverse organisations of many different acronyms. This internationalism proved to be, through its revolutionary, anti-fascist and anti-imperialist scope, both more enduring and more global than the International which had given it life. In what ways did the Comintern serve as a 'start-up' for worldwide projects and struggles which have left their imprint on the contemporary world, in particular outside of Europe? In this article we try to offer some answers to this question.

We should note from the beginning that our inquiry would not have been possible without recent innovations in the field. Communism is transnational, but we needed the perspective of transnational history to be able to think about it as such. For a long time works on communism (as on other topics) had been bound by a nationally-minded framework, a mode of analysis which favoured country-by-country studies of national parties and organisations 
and their individual relations with the epicentre that was the Soviet Union.

\section{Archives and controversies}

Let us assess the developments of the 1990s onward. After the collapse of the USSR and the opening of the archives, the former Marx-EngelsLenin Institute - which houses the archives of the Comintern and the CPSU - for a few years became the Mecca of western specialists on communism. ${ }^{1}$ These specialists searched the open records for - at last - definitive answers to old questions. Had Communist parties been vassals to Moscow, or did they represent deep-rooted, autonomous and authentic political forces? What are we to make of Annie Kriegel's description of Bolshevism as a graft onto the labour movement? ${ }^{2}$ After Lenin, had Stalin and the Communist International betrayed the revolution and sacrificed internationalism on the altar of Soviet state interests? These questions had animated debates over the history of the twentieth-century left, conflicts between advocates of a teleological and a societal conception of communism, and - in the context of Soviet history - between those who emphasised the centrality of ideology and those who instead saw realpolitik at work. They were questions which related to the division of the entire field between the totalitarian and revisionist schools. The debates were academic but also political, erupting one final time in the 1990s as a result of the controversy stoked by The Black Book of Communism. ${ }^{3}$

The historiographical work of the 1990s made it possible to draw a first map of the Comintern system, a map which placed Moscow firmly in the centre and essentially limited the perspective to the continent of Europe. Amsterdam's International Institute of Social History and the periodical International Newsletter of Historical Studies on Comintern, Communism and Stalinism provided means for academics to circulate findings from the archives relating to internal processes and leading personnel. ${ }^{4}$ On issues such as strategy development, financing and logistic support, the creation of communist cadres, surveillance and repression, it was revealed that Moscow's tutelage had been inescapable, and a certain periodisation was confirmed: 5 the 21 
conditions of admission to the 1920 Congress, the Bolshevisation of parties in the mid-1920s, the Stalinisation of the 'class against class' period beginning in 1928, and the purges of 1936 to 1938 . Without a doubt one of the most innovative parts of this work was the study of the small group of 'Cominternians' (roughly 400 cadres in the mid-1930s), that is to say those men and (relatively few) women who populated the leading structures of the International or acted as its representatives in various countries. High-quality data from personnel dossiers opened up immense possibilities for prosopographical and biographical research into these Cominternians, and revealed singular tales of globe-trotters: ${ }^{6}$ transnational European lives like that of Eugen Fried, but also lives played out on the global stage such as that of the Russian multiple emissary Mikhail Borodin (real name Gruzenberg; 1884-1951), 'Stalin's man'7 Studies of the International missionaries' supervision of the parties also revealed the subtle and complex interplay between the instructions issued from the centre and the initiatives taken by the periphery.

However, Moscow's sway over transnational protest movements went beyond the framework of the Communist International itself. Indeed, historians working during these years on Soviet foreign policy discovered the extent to which the Soviet regime had known how to construct an exterior system of public relations capable of winning sympathy and allegiances well beyond communist circles. Archival research contributed to a re-evaluation of the duality between the objectives of the Comintern and those of Soviet diplomacy. This became apparent most of all through the division of labour between diplomats, scientific and cultural attachés, party activists, party leaders and intelligence officers. The common mission of these diverse posts was to break through the barriers of anticommunism and open up new opportunities for furthering the cause jointly championed by communism and the Soviet Union. This system of public relations, then, was like a multitude of microcosms of agitation, propaganda, mobilisation and influence, each one of them developing its own specific strategies and networks. ${ }^{8}$ Were these inventive forms of savoir-faire working for the Soviet state or for revolutionary internationalism? The studies quite largely contradict the Trotskyist thesis that Stalin had abandoned internationalism. Archival

Twentieth Century Communism - Issue 14 
documents revealed a violent, power-hungry and paranoid man, but they also brought back into view the strongly ideological compulsion animating his political action. Indeed, Stalin came to appear as a staunch Bolshevik in Lenin's wake, driven by the international class struggle. ${ }^{9}$ But he conceived of this struggle as a projection of the internationalism internal to the proletarian motherland; the priority, then, had to be the modernisation and close protection of the state against all internal and external enemies.

This history written at the start of the 2000s was therefore a very predominantly European history. ${ }^{10}$ The change in direction of the Third Period (class against class) was interpreted in relation to the increasing sectarianism of European communist parties incapable of halting the rise of fascism. The adoption of the Popular Front policy was understood as a French invention, a result of the common work of Eugen Fried and Maurice Thorez. Studies of the war in Spain focused particularly on European brigaders who joined republican forces and on the repression of anti-Stalinist factions. The German-Soviet Pact was (rightly) presented as a shattering blow for anti-fascist activists in Europe, but little was said about what it meant for communists elsewhere. These kinds of perceptions on communist history had been widespread among the ruling circles in Moscow and the European communist parties; but by and large, they simply ignored how communists outside of Europe (including within the Soviet Union) would have seen things.

\section{New approaches}

After a drop in the number of studies on communism at the beginning of the 2000s, we may identify in the past decade - stimulated by an epistemological renewal - a reinvigorated interest in the history of internationals, marxisms and communisms.

To begin with, the changing intellectual and political context driven by postcolonial thought and subaltern studies - has exerted a clear influence on the research on international communism in recent years. This development can be seen in the rediscovery of the dynamic bonds forged between communism, anti-colonialism and anti-imperi- 
alism in the wake of the October Revolution. The 'Wilsonian moment', indeed, found a clear answer in the Leninist moment. ${ }^{11}$ Both men advocated the right of peoples to self-determination; but only Lenin refused to limit this right to European peoples aiming to construct a state, extending it instead to all national minorities and all colonised peoples. It is true that Bolshevik action towards non-European peoples (within and outside of the Soviet Union) was marked by orientalism and a stageist understanding - categorising peoples on a scale from 'advanced' to 'backward'. But it is also true that the Soviet Federation had an affirmative action policy in favour of non-Russian nations; ${ }^{12}$ and that the International enthusiastically engaged with the question of colonialism as well as the problem of racial discrimination, notably in the United States. The International became an essential point of contact for all anti-colonialist, pan-Africanist and anti-racist movements around the world. The Baku Congress of 1920 and the foundation of the Communist University of the Toilers of the East (KUTV), as well as debates on the colonial question, led to interactions between the leaders of the Communist International and representatives of oppressed societies such as the Indian M.N. Roy (1887-1954) in 1920 and the black American Harry Haywood (1898-1985) in 1928. In this way, the study of international communism can be integrated into the wider study of the internationalist moment, which was triggered by the First World War and from which point non-European peoples started to make themselves heard. ${ }^{13}$

The renewed interest in the history of international communism is also the result of the essential role played by the transnational perspective, which has allowed for a re-evaluation of earlier histories of the labour movement. ${ }^{14}$ Indeed, the study of workers' internationals today easily fits into a broader history of transnational solidarities between dominated groups, with the years 1860 to 1940 being especially crucial. In this history the objects of study go way beyond the working class to encompass women, national minorities and victims of persecution, repression, conflicts and wars; ${ }^{15}$ and international solidarity is studied from the perspective of organisations and groups. A great deal of importance is placed on contacts, connections and conflicts, but just as much emphasis is given to what Pierre-Yves Saunier calls the 'infrastructures

Twentieth Century Communism - Issue 14 
of causes': ${ }^{16}$ the material life of objects, people, practices and ideas in circulation. Studies also have to grapple with the ways in which internationalism has been organised, subjected as it has been to technical, social and police infrastructures which could stimulate or restrain it. This field of study is huge, despite certain difficulties in accessing data and in interpreting the documents which are available. Cominternian activities had to be done in secret, requiring pseudonyms, fake passports and a continual search for reliable ways of passing on money and political material. The transnational-level study of communist labour organisations and trade unions reveals a world of recruitment, liaison and exchange; a world in which men, money and propaganda moved around despite the intense surveillance of imperial police forces, as shown in studies on the transcontinental union branches of the Profintern (the Red International of Labour Unions) such as the Pan-Pacific Trade Union Secretariat at Hankou or the International Trade Union Committee of 'Negro Workers' at Hamburg. ${ }^{17}$ We might also mention here the fascinating but complex history of the network of seamen's interclubs founded in ports along merchant navy navigation routes, from Archangelsk to Rotterdam via Petrograd, Odessa, Sebastopol and Murmansk as well as Le Havre, Rouen, Dunkirk and Marseille, with Hamburg at the epicentre. ${ }^{18}$

Finally, in the wake of the Alltagsgeschichte and as a result of the extraordinary wealth of biographical and autobiographical material in the Comintern archives, the social and cultural history of communism has acquired a new dynamism. ${ }^{19}$ Moving away from structural analysis (or at least trying to do it differently), the focus has instead been on putting daily social practices at the heart of things, thinking about actors' experiences and how they made sense of the world. Being communist was undoubtedly a matter of ideology, but it was also a way of life. To become communist necessitated a learning process which could turn out to be long and difficult. Staying communist demanded a permanent process of self-work. The exploration of subjectivity has opened up new perspectives, as can be seen in the studies on international cadre schools and those on the processes of self writing asked of communists. ${ }^{20}$ The renewal has also focused on the polysemy of words used by activists and leaders the 
length and breadth of the communist world, representing a sort of belated recognition of the history of concepts (the Begriffsgeschichte) and the linguistic turn. What indeed did internationalism mean for a Bolshevik emerging from the civil war, a Tajik from Central Asia, a Parisian worker or an Indian confronted with British imperialism? What is the relationship between the formalised and organised internationalism of the Comintern and the subjective internationalism of the International Brigades volunteer? What use was made of internationalism by the Soviet Union, which up to the 'Great Patriotic War' made The Internationale its 'national' hymn?

As we can see, there are several motivating factors behind the renewal of international communist history. The supply of sources from the Russian archives has also played its part.

\section{Temporalities and spaces of utopia: explorations}

The new history of transnational communism offers some food for thought on temporality through a return to the beginning of the $1920 \mathrm{~s}$ and a 'rehabilitation' of the 'class against class' period. The first years are now seen as of greater interest, while twenty years ago scholarship was focused on the Stalinist period. Should we understand this as a consequence of the craze among historians for Reinhart Koselleck and his 'horizons of expectation', an interest in utopia before it becomes warped and disappointing?21 It does entail the study of a moment rife with possibilities, that of 1917 and its consequences, when the history of revolutionary hopes met with the reality of a revolution taking place on the specific terrain of Tsarist Russia; it was also the moment when lineages such as that of European and particularly German social democracy were reinvented in a new synthesis of cultures, doctrines and forms of activism. ${ }^{22}$ The creation of the Comintern in 1919 was an attempt to keep this élan going. Among the new generations mobilised by the central European revolutionary movements, some decided to get involved despite the rapid worsening of the political situation. Activists from other parts of the world were soon attracted by the radical nature of this 'proletarian' internationalism after the failure of the Second International, as well as by its anti-capitalism and ground-breaking anti-

Twentieth Century Communism - Issue 14 
colonialism; and it is precisely the study of this non-European communist activity which makes possible a revisiting of the Third Period from an entirely different perspective. Seen from Europe, the Third Period had looked like a sectarian withdrawal compared with the 1920s and with the productive time of the popular fronts which followed it. From outside Europe it appears by contrast as the decisive meeting-point between the communist movement and anti-imperialist and pan-Africanist currents. Anti-imperialist activists welcomed as proof of radicalism the social struggles in the context of the 1929 crisis, as well as the no-compromise stance towards the political forces of the traditional left which led to the formation of the organisations of the Third Period. By contrast, the turn towards the popular front appeared to some - as did the USSR's ambivalent position in the Italy-Ethiopia conflict - as the beginning of the Communist International's betrayal of the cause, well before the German-Soviet pact.

This new history also offers a reappraisal of the cartography of the communist world, fundamentally decentring our perspective and moving it away from Moscow. The communist 'nebula' (Annie Kriegel) is increasingly studied from a peripheral angle, in which it overlaps with other worlds of protest - feminism, anti-colonialism, socialism, pacifism, anti-fascism - sometimes, incidentally, at the risk of forgetting the power of the Soviet machinery and party. For some time there has been an astonishing renewal of interest in Willi Münzenberg (1889-1940): an international congress about him was held in Berlin in September 2015, and there is a website dedicated to his study. ${ }^{23} \mathrm{Up}$ to now, research on Münzenberg has focused particularly on his wide range of humanitarian and anti-colonialist organisations (including the League against Imperialism and for National Independence, founded in 1927) as well as his entrepreneurial activity in the press, publishing and cinema. ${ }^{24}$ Another point of focus has been communist activity in regions of what has long been known as 'the periphery': China, India, south-east Asia, Latin America and sub-Saharan Africa. However, there is still much to be written about the extra muros spaces of communist activity which - though linked to the centre in Moscow - were nevertheless levels of political action in themselves. Thus we still know little about the Comintern apparatus's advance posts planted on the outside 
of the USSR, such as the Westeuropäisches Sekretariat (1919-1925) and subsequently the Westeuropäisches Büro (WEB; 1927/1928-1933) of Berlin, which was run at one point by Manuilsky and then soon after by Dimitrov. The list of these institutional staging posts, tools of revolutionary expansion across the world, is long: we could mention Montevideo, Shanghai, Amsterdam, Paris, Prague and many other places which have not yet received enough scholarly attention. Within the USSR itself, the Bolshevik party offices at Baku, Tashkent and Irkutsk - built initially within the context of their respective republics and then that of the Soviet federation - are deserving of study as crucial actors in the strategy to expand the revolution into neighbouring countries. $^{25}$ This new historical approach clearly shows what is to be gained from studying the zones of contact, the overlaps, the go-betweens, in short all these vantage points which question the dividing lines established by traditional historiography between national and international, Muscovite and foreign, communist and non-communist. Borders have, then, turned out to be shifting and much more porous than we had once thought.

\section{Communist men and women}

Communists around the world recognised each other by the acronyms, songs, gestures and expressions which circulated amongst them. They had common heroes like Dimitrov after the Leipzig trial and founding texts such as Stalin's History of the Communist Party of the Soviet Union (1938). Even when they didn't understand each other, a song like The Internationale could bring them together. The Turkish writer and KUTV graduate Nâzım Hikmet recounts in his autobiographical novel The Romantics that students sang The Internationale together, each in his or her mother tongue, and that only the word 'international' was the same in each language (except in Chinese). However, the meaning of words and ideas is dependent on situation and place, and this sometimes led to misunderstandings. ${ }^{26}$

Meetings and experiences influence how actors perceive the world. The identity of communist activists was multiple and mutable in several ways. This is true first of all in the literal sense: they had to adopt

Twentieth Century Communism - Issue 14 
numerous pseudonyms to carry out their various duties, and in the course of their missions they mostly travelled with fake passports. M.N. Roy was one of the founders of the Mexican Communist Party, worked for a time at Tashkent in the Far East bureau and then carried out a mission in China. His real name was Narendra Nath Bhattacharya, but aside from Roy he used another four assumed names, while (to take another example) Georgi Dimitrov had no fewer than thirteen. ${ }^{27}$ But these activists' identities were mutable also in the sense of their appropriation of subjective orientations and dispositions which were 'truly Bolshevik', partly through training in the USSR's international cadre schools. At first these schools were improvised, such as in Tashkent where it was set up shortly after the Baku Congress in 1920, but centralised Comintern schools were created in 1921: the Communist University of the Toilers of the East (KUTV) for activists from colonial countries, and the Communist University of the National Minorities of the West (KUNMZ). It is precisely with the 'Bolshevisation' of the International that the latter set about creating cadres with a global perspective, through making promising activists of foreign communist parties come to Moscow. The International Lenin School (ILS) welcomed its first 70 students from 22 different countries in 1926, and an estimated 3000 communists received training there by the time of its closure in 1938. ${ }^{28}$ Despite the difficulties of cultural adaptation and communication (more than twenty languages across seven linguistic groups were spoken there), changes in the political line, and forms of control which ranged from the fussy to the oppressive, the ILS worked as a space of unification via ideology and habitus, but also of communist subjectification and transnational exchange. National cultural and linguistic differences were 'transcended' via common goals and activities. ${ }^{29}$ The framework of references and cultural practices underpinning the communist world thus contributed to a sense of common belonging. ${ }^{30}$ Nevertheless this development of activist identity, through the shaping of their world-view, did not prevent dissidence, defections and expulsions (including that of Roy in 1928).

The role played by actors, their agency, is indisputable when viewed from this new perspective. Having sometimes remained hidden behind structures, it has now come to the fore. As in the case of Lamine 
Senghor in 1927, an activist stepping down or dying could lead to an abrupt halt in activity and a dissolution of networks. Münzenberg is far from the only individual to have attracted scholarly attention in recent years. Particular attention has been paid, first, to activists from colonies or 'semi-colonies' or those who were national or 'racial' minorities, like the aforementioned Roy, George Padmore (born Malcolm Ivan Meredith Nurse; 1900-1959), Henk Sneevliet (known as Maring; 1883-1942), Tiemoko Garan Kouyaté (1902-1944) and José Carlos Mariátegui (1895-1930); and, second, to transcontinental envoys such as the Hungarian József Pogány (known as John Pepper; 1886-1937), who was permanently on the run after the council revolution was crushed in 1919, and who passed through Austria, the Soviet Union, Germany and the United States before finally succumbing to Stalin's Terror. ${ }^{31}$ We may note the quasi-absence of women, which is of course a reflection of their low status within the Comintern hierarchy, though doubtless also of their relative scarcity among anti-colonialist activists. There are not many recent biographies on communist women, though exceptions include works on the Italian Tina Modotti (1896-1942), a photographer, model and transnational collaborator for International Red Aid; the American Agnes Smedley (1892-1950), feminist author and an agent of the International Liaison Department (OMS) in China; and the Austrian Ruth Fischer (born Elfriede Eisler; 1895-1961), who was for a time at the head of the powerful German party. ${ }^{32}$ At a lower level of responsibility we could mention the black communist women from Harlem Maude White and Hermina Dumont Huiswoud, who spent three years in the USSR - one at the KUTV and the other at the International Lenin School - before activity in Belgium and France. ${ }^{333}$

We see therefore that there were many Cominternians who, through their socialisation and way of life, were travellers between contexts, cognoscenti of different cultures - cosmopolitan actors, to put it concisely. As Sidney Tarrow has claimed, they were nonetheless anchored in transnational social relationships, connected to specific places and constituting parts of particular networks. ${ }^{34}$ These actors were not straightforward executors of Moscow's will; they often followed their own agenda, and sometimes acted contrary to directives or opposed the line, as did Padmore and Münzenberg. Their local

Twentieth Century Communism - Issue 14 
knowledge gave them a real advantage over the Muscovite 'centre' when it came to choosing political tactics. Besides this, it was sometimes simply difficult to relay information, or new directives might arrive late and links could be cut. In these circumstances they had to make their own decisions.

\section{Getting beyond the eurocentrism of Comintern history}

Historiography most often attributes the turn to Asia to the failure of the German revolution in 1923 . But already by 1920 , at the second congress of the Comintern, there were several debates and resolutions on the 'colonial question'. The Baku Congress in September of the same year, through a first multinational meeting, made concrete the policy to support nationalist revolutionary movements of the 'oppressed peoples' of the East. ${ }^{35}$ The Profintern for its part was engaged in the anti-colonial struggle in Asia from its first congress in 1921, and in December 1922 it founded the Eastern Bureau to this end.

There was undoubtedly a certain Eurocentrism. The Comintern's Europeans revealed an 'evolutionist' stance towards the Asians: 'We must help our more backward comrades in Asia attain the front ranks', according to an appeal by the Profintern launched at the time of the Federation of Maritime Workers congress in Moscow in 1925.36 Moreover, the anti-colonial struggle was often considered not as an end in itself but as a means to stoke revolution in Europe through attacking the 'weak links'. Did Trotsky not claim in August 1919 that 'the road to Paris and London proceeds via the towns of Afghanistan, the Punjab and Bengal'? Besides, the category of 'class' was more important than anything else: for instance, the oppression of Africans and AfricanAmericans was seen as a class oppression first and foremost. This limited the possibility of taking into account other systems of discrimination, just as it did in the case of the oppression of women.

Thus there were frequent disagreements between indigenous communists whose priority was decolonisation or ending racial discrimination (Roy, Ho Chi Minh, Padmore) and the 'whites' in Europe, the United States, Moscow or in the colonies, for whom the priority remained working-class emancipation. 
However, it has been noted that certain contextual similarities between the former Russian empire and the colonial or 'semi-colonial' empires sometimes made it much easier for activists from those countries to communicate with the multinational Bolsheviks of Russia than with European communists. The particularity of the 'great Asian peasant nations' was emphasised by Lenin himself, and the Soviet Union promoted affirmative action towards non-Russian members of the new federation. Communists of oppressed regions found this striking, and so communists in colonial states - notably in Algeria or the French Antilles - would sometimes lean on Moscow for support against their French comrades-in-arms. ${ }^{37}$

Finally, we must emphasise the extent to which the struggles against the persecution and for the elevation of European national minorities (Ukrainians, Belarussians, Irish and Alsatians) were conceptually linked with the same struggles of colonised peoples. This link was manifest in Soviet propaganda, as in the campaigns of the League against Imperialism, in which aspiring nations in Europe and beyond were put on an equal footing under the banner of the anti-imperialist struggle. Likewise, the fight against fascism was to play out in Europe but also beyond it, notably in the double context of the wars in Abyssinia and Spain. The perception of continuity between the struggles on every continent was therefore an absolutely central element of communist internationalism.

There were, then, some very dynamic attempts to organise the 'oppressed peoples' on almost every continent, including the Indians, black Americans, Africans, Chinese and the indigenous peoples of Latin America. These attempts first targeted those countries most directly accessible from the revolutionary heartland, namely China and India. The British government was the first to become aware of this, and particularly from the third Comintern congress onwards it worried about the communist threat in India. This concern was demonstrated by, amongst other things, the creation of an antiBolshevik committee at the behest of Edwin Montagu - Secretary of State for India from 1917 to 1922 - and the Peshawar trial of March 1923 against seven Indian activists who had been trained in Tashkent and Moscow. ${ }^{38}$ The attempts to destabilise India from Tashkent, 
Kabul and Berlin were indeed joint efforts by Soviet diplomats (Lev Karakhan, Yakov Surits, Fyodor Raskolnikov), Cominternians like Roy and radical groups of Indian political exiles. ${ }^{39}$ China was a different case, regarded as the passageway for agitation in French Indochina. Guangdong was a hotbed of revolutionaries in contact with Thailand and Japan, and home to many Vietnamese political exiles. So, while around sixty Vietnamese activists studied in Moscow's Comintern schools between 1923 and 1940, two hundred received training from the Huangpu Military Academy which was founded by Sun Yat-sen in the spring of 1924 under the auspices of International agents and Soviet military advisors. ${ }^{40}$

However, we must not exaggerate the choices open to the Comintern and the Soviets; to be successful, they needed strong activism on the ground. There has been an abundance of historiographical work on the social and political movements within the colonial societies in which local communists were active. These works show the difficulties in understanding the forms of interaction between local struggle and global movement, and in bringing together two historiographies which have ignored each other for a long time: that of communist internationalism and its organisations, and that of the social and political struggles which led to decolonisation. Kris Manjapra thus emphasises the need to grasp a phenomenon like Indian communism on a transcolonial level, as a multipolar form of activism organised around a constellation of spaces among the diaspora and within the Indian subcontinent. ${ }^{41}$ Elsewhere, in those communist parties which tended to neglect the anti-colonial struggle, anti-colonialist, anti-imperialist and anti-racist activists sometimes found themselves in a tough situation. The directives and calls to order issued by Comintern authorities were not always enough. For instance, the American party - aside from the issue of black Americans - showed little interest in the defence of different immigrant communities. Josephine Fowler shows this in her study on Japanese and Chinese immigrants, who generally found themselves alone when developing strategies and organising on the local level. It was these same immigrants, however, who served as points of contact with Asian seamen in the transnational networks of the Pan-Pacific Trade Union Secretariat, on the Pacific and Atlantic coasts of the 
United States. ${ }^{42}$ Indeed, the first portside offices set up from 1923 by the Profintern in Rotterdam and Vladivostok lacked staff who could speak Asian languages, notably Japanese and Chinese; consequently it was local Japanese and Chinese activists who had to board Asian vessels to try to make contact with sailors. Anti-colonial activists played an intermediary role in other countries, too, again underscoring the importance of these actors: for example, it was Kouyatés visit to Berlin in 1929 which made possible a formal association between Africans and communist organisations in Germany. ${ }^{43}$

It is in fact easier to trace the Comintern's activities where there were anti-imperialist and anti-colonialist activists among the diaspora or in the imperialist countries. Recent works have therefore looked at the pan-Africanist networks of 'Black Bolsheviks' in the Caribbean, United States, France, Britain and Germany. ${ }^{44}$ Others have more particularly studied the meeting-places and spaces which were the 'global' cities where exiled activists regrouped: Paris in the interwar period for Chinese, African and Latino anti-colonialists and revolutionaries, Berlin or London and the British port cities of Cardiff and Liverpool for Africans. ${ }^{45}$ Ho Chi Minh, while still known as Nguyen Ai Quoc, had left Indochina at the age of 21 and from 1911 worked as a seaman in the United States, Britain and Africa. In 1917 he moved to Paris and founded the Association of Annamite Patriots, which grouped together Vietnamese exiles in France. After placing his hopes in Wilson to deliver the 'right of peoples', to no avail, he joined the Third International. It is thus in Paris that he was to play a leading role in the organisation of activists from the colonies, and it was here also that he met young Chinese activists like Zhou Enlai and Deng Xiaoping, who, like him, lived near the Place d'Italie.

The worldwide anti-imperialism of the time, then, mostly unfolded in the capital cities of imperialist nations. These cities offered activists validation and a flattering reflection, and served to valorise local struggles, the knowledge of which extended across borders via congresses, networks of correspondents and above all through newspapers, which gave shape to a space of transnational circulation. The Negro Worker played an essential part in this. Münzenberg's League against Imperialism was the guiding light. ${ }^{46}$ It was admittedly a distant light

Twentieth Century Communism - Issue 14 
for the majority of those living under colonialism, and often dimmed by storms (violent tensions, withdrawals, ruptures), but it was a light nevertheless.

\section{Communist internationalism: A certain savoir-faire}

Communist internationalism was able to contain within itself a very wide array of significations, intentions and practices. It underwent some deep transformations through time, but also across the various spaces in which it could find support.

For politically engaged Soviet citizens, internationalism was first of all a domestic practice - that of friendship between peoples within the framework of the Soviet federation - though it equally signified (as it was presented in propaganda) a form of altruism and responsibility towards the workers and exploited people of countries still under the capitalist yoke. However, Soviet citizens were generally deprived of any real possibility of acting according to their internationalist leanings. Thus, those who wrote to Dimitrov to ask for permission to fight alongside the Spanish republicans in 1936-1937 were refused; the only ones to participate in the civil war did so within the institutional framework of the army and the NKVD (People's Commissariat for Internal Affairs). ${ }^{47}$ For western sympathisers of revolutionary Russia, internationalism could take the form of mutiny on the Black Sea to halt an anti-Bolshevik intervention; humanitarian aid to starving Russian children at the end of the civil war; or moving to the USSR at the start of the 1930s, as did some Finns; or leaving home to build a red future in Karelia or Birobidzhan, as did some American Jews. ${ }^{48}$ For partisans of anti-fascism, the most highly-esteemed form of internationalism was that of the International Brigades volunteers. ${ }^{49}$ But among the roughly 40,000 brigaders there were in the Abraham Lincoln Brigade around ninety black activists from the United States, for whom the battles against fascism and against racism could not be separated. ${ }^{50}$ For all communist partisans the struggle was that of the exploited and oppressed on the international level, whatever form this might take. As for how this internationalism was put into action, the savoir-faire of the International and of its extensive network of organisations was decisive. 
The form most commonly taken by this internationalism during the period was that of international solidarity. ${ }^{51}$ According to Braskén, this solidarity was simultaneously a combat weapon and a cultural value. It represented an emotion, a feeling of belonging, and could serve as an end in itself. 52 International solidarity, as organised by Comintern circles and the milieus surrounding them, took many forms. These ranged from mutual aid (the collection of funds, petitions) and collective denunciations of injustice (demonstrations, petitions) to kinds of action - such as the strike, the boycott or armed struggle - which were sometimes high-risk, particularly in the colonial countries (where repression was severe) and on the battle-fronts of the Spanish civil war. Thanks to a transnational network of lawyers, International Red Aid and the International Juridical Association were able to offer support to activists charged by the legal system..$^{53}$

Mobilisation campaigns for a cause sometimes lasted for years, with intense peaks in activity within this, and they contributed to the creation and strengthening of a web of relationships across countries and continents. Many of these transnational moments of international solidarity have received their due attention. Some of the campaigns related to momentous trials: for the freeing of Sacco and Vanzetti between 1921 and 1927, to exonerate the young African-Americans of Scottsboro wrongly convicted of rape between 1931 and 1937, to support the activists charged in the trial known as the Meerut conspiracy in India in 1929-1932, for the freeing of the 'Noulens/ Rüegg' couple (who were in fact Comintern agents) arrested in China in 1931, or to oppose the Leipzig trial of 1933-1934. ${ }^{54}$ As Michael Goebel emphasises, although it was not universalist, the 'transnational solidarity' of the Cominternians and particularly of their anti-colonial activists was global in the sense that it was addressed not to a single, directly-concerned 'people', but in fact to all peoples, and to the very broad category of the oppressed. 55 Despite a certain asymmetry in communist depictions of the European worker and the indigenous worker living under colonialism - in terms of their capacity for autonomy and power - the latter was nevertheless not seen as a simple victim in need of help. International solidarity was directed towards the oppressed who were already fighting and who were, very often,

Twentieth Century Communism - Issue 14 
organised. These were comrades or at least brothers in the fight against capitalism. In the Meerut trial, three British trade unionists stood shoulder to shoulder with their Indian comrades in the docks.

Other mobilisation campaigns took the form of responses to international crises. Researching the first efforts in this area contributes to the renewal of the history of international relations through the study of collective emotions. Apart from the practice, beginning in the early 1920s, of publishing so-called white, yellow or other such books on atrocities committed by the opposite side, emblematic of these collective emotions were movements like 'Hands Off China', whose slogans linked together the denunciation of Japanese imperialism in China and the defence of a USSR threatened by the annexation of Manchuria; and the 'Hands Off Ethiopia' campaign of 1935-6, which emphasised the connections between the denunciation of European imperialism in Africa and the fight against fascism, and which was very successful in mobilising the ranks of anti-colonialist activists. ${ }^{56}$ These political campaigns were not exclusively communist mobilisations; for example the campaign against the war in Abyssinia actually made things awkward for Cominternian networks boycotting Italian goods in ports, as the Soviet Union continued to export petrol to fascist Italy.

\section{Tragic end and after-life of the 'start-up' of global internationalism}

In the second half of the 1930s - at the time of the antifascist moment which helped to swell the ranks of communists in a number of countries - there was a fundamental break between the transnational solidarities which had been stimulated by the Comintern's networks since the beginning of the 1920s, and the International itself, which was going through a difficult period. The International of the second half of the 1930s was characterised by a struggle against deviations and the denunciation of Cominternians who had allegedly been too enterprising. Padmore was expelled from the Comintern in 1934; Münzenberg was under threat of it from 1936 onwards. In 1937-38, the Stalinist repression decimated the ranks of Soviet communists as well as foreign communists who happened to be in the USSR. In Stalinist politics, from out of the heart of Soviet patriotism there emerged a xenophobia 
rooted in the obsessive surveillance of the proletarian homeland's borders and fear of the fifth column. In December 1935, the special border passages for communist cadres and partisans active in Poland were closed down. In 1936, the NKVD and Soviet military intelligence were tasked with scrutinising the entire contingent of political émigrés who had been welcomed into the USSR on the recommendation of International Red Aid, the Comintern or the Profintern; the aim was to reveal any double agents. Foreigners and those with links to foreign lands became suspect, even if they were communists, and the asylum policy for activists persecuted by European fascism was placed under serious scrutiny. ${ }^{57}$ To this we might add - subsequent to the Kirov assassination - the hunt for all former opponents and Trotskyists accused of collusion with the Gestapo on Soviet soil, a hunt whose targets ranged from those within the ranks of the International to those as far away as the fronts of the Spanish civil war. In this context many Cominternians tried to gain some distance, indeed to flee from the repression that awaited them.

But these years were also marked by a growing disaffection. The ranks of the 'International' of former International members grew and grew: Münzenberg, Padmore, Sneevliet, Roy, Mariategui, Lucie Colliard. A number of Cominternians no longer accepted the stifling vertical hierarchy which connected them to Moscow, or the servile alignment of the International with Soviet diplomatic priorities when the latter was pushing for the downplaying of anti-imperialism so as to facilitate mutual support between France, Britain and the USSR against Hitler. Furthermore, after 1939 others were to abandon ship in horror at the Stalin-Hitler pact, notably Jews for whom communism had been the spearhead in the struggle against antisemitism in Russia and elsewhere.

However, despite the purges and the seemingly treasonous policy turns, the Soviet Union remained the most important place of exile for the core group of communist officials of wartime Europe. The few works about the Comintern during the war show that at the time of Hitler's invasion its offices were evacuated to the Urals, to Ufa. ${ }^{58}$ This is where the work on which the Comintern was focusing at the time - propaganda, intelligence and training - was reorganised, in co-ordination

Twentieth Century Communism - Issue 14 
with the political bureaus of the communist parties whose leaders were then taking refuge in the USSR: Walter Ulbricht (Germany), Maurice Thorez (France), Dolores Ibárruri (Spain), Palmiro Togliatti (Italy), Klement Gottwald (Czechoslovakia), Mátyás Rákosi (Hungary), Otto Kuusinen (Finland), Ana Pauker (Romania) and so on. A centre of radio transmitters broadcasted to European countries.59 There were training schools for the Spanish, Chinese and Austro-Germans, and, from March 1941, for 65 Slavic cadres destined for eastern Europe. ${ }^{60}$ Once the USSR had entered into the war, a special political and military school prepared national groups for armed insurrection. The international dimension of communist parties' activity narrowed to Eurasia, and was now more than ever understood as solidarity with the Red Army and the Soviet state. It was in this context that, from 1941, Stalin planned a wholesale change in the general staff of Lenin's revolution. The Comintern thus dissolved itself in May 1943, through two Presidium meetings. From this point onwards, an international information department within the Communist Party of the Soviet Union was to be responsible for contacts with foreign communist parties. After Stalingrad, and given the links created by war and exile, Stalin had nothing to fear from the Comintern's dissolution. By now his cult of personality was part of the foundations of international anticapitalist solidarity on the post-war Eurasian continent.

However, the after-effects of communist internationalism can be found beyond the close-knit Stalinist circles of wartime and the European Stalinism of the Cold War. There is no doubt that the third-worldist offensive launched by Khrushchev after Stalin's death, and in the context of the non-aligned movement, awakened many of the impulses of communist internationalism and anti-imperialism of the interwar years. The affirmative action policy which had benefited non-Russian nations within the Soviet Union in the 1920s was later extended in an educational context to all nations undergoing decolonisation, notably with the foundation of the Lumumba Peoples' Friendship University in $1960{ }^{61}$ Moreover, and from this point onwards far-removed from Moscow, networks and individuals continued their fight for social justice and decolonisation with a savoirfaire of subversion and agitation-propaganda learned from their earlier 
engagement or apprenticeship with communists. The experience of radical pan-African platforms like the League against Imperialism and The Negro Worker were not forgotten after the war. Despite an obvious break in doctrine, the foundation of Padmore and Kenyatta's radical pan-Africanism in 1945 nevertheless bore the partisan stamp of pre-war global communism. ${ }^{62}$ The influence of the anti-imperialist internationalism of the interwar communist forums on the development of Nehru's Indian anti-colonial nationalism has already been established. ${ }^{63}$ In Latin America the impact of the Comintern's marxism and anti-imperialism on radical elites has proved to be lasting. According to other works, in the actions and writings of the (few) black female communist leaders in Harlem from the end of the 1930s, we can identify the theory of triple oppression (working-class, black, female) and the intersectionality of the civil rights movement and of second-wave feminism in the United States. ${ }^{64}$ Recent historiography thus brings to light many forgotten threads connecting the anti-imperialist struggles of the old communist left to those of the decolonising third world, showing in particular the internationalist transcendence of colonial, national and imperial borders and the development of a global way of thinking.

Through this presentation of recent historiography on communism and the International, we hope to have provided the tools necessary to think through the equation of communism + transnational. Today the communist nebula is approached as a multitude of social movements and through its actors, rather than via questions of state machinery and power; through the lens of networks rather than the centre-periphery dichotomy; and through the study of cross-border movement rather than via a national perspective. Thus, communist internationalism has gained in complexity. It appears as something permeable to the other big ideas of the time, and offers a fresh perspective on the many actors who - through their subjectivity, their skill and their room for manoeuvre - were very far from being the docile pawns depicted by older studies. The importance of communist spaces, and of the multilevel games which played out between the local and the global, also starts to appear as a key to understanding just what it might have been - this global movement in which ideas travelled and were transformed 
in the course of their journey, in which local, national and international chronologies came together or showed themselves to be completely out of step with each other. But there is still much to do in this vast renewed field of global communism, and the task of giving due attention to the shadow and the light cast by one of the most important political experiments of the twentieth century.

\section{Translated by Gareth Price-Thomas}

\section{Notes}

1. We are referring to the Russian State Archive of Socio-Political History (RGASPI).

2. Annie Kriegel, Aux origines du communisme français (1914-1920), Paris, Éditions Mouton \& co, 1964.

3. See for instance the sometimes virulent debates in the United States in the 1980s between Theodore Draper and the proponents of a 'new left', so-called revisionist, history: New York Review of Books, 9 May, 30 May, 15 August and 26 September 1985; Stéphane Courtois et al (eds), Le livre noir du communisme. Crimes, terreur, répression, Paris, Éditions Robert Laffont, 1997; Michel Dreyfus et al (eds), Le siècle des communismes, Paris, Éditions de l'Atelier, 2000.

4. See the proceedings from the first international colloquium at Moscow: Mikhail Narinsky, Jürgen Rojahn (eds), Centre and Periphery. The History of the Comintern in the Light of new Documents, Amsterdam, International Institute of Social History, 1996. Founded at the beginning of the 1990s by Bernhard Bayerlein and a team of young German, Russian and Swiss researchers, The International Newsletter of Communist Studies (INCS) - as it is called today - can now be found online: http//incs.ub.rub.de.

5. Brigitte Studer, Un parti sous influence. Le parti communiste suisse, une section du Komintern, 1931 à 1939, Lausanne, Éditions L'Âge d'Homme, 1994; Narinsky \& Rojahn, Centre and Periphery.

6. Among the biographical dictionaries of the labour movement (a genre of work started by Jean Maitron), there is a book on Cominternians for French-speaking Europe: José Gotovitch and Mikhail Narinski 
(eds), Komintern: l'histoire et les hommes. Dictionnaire biographique de l'Internationale communiste en France, en Belgique, au Luxembourg, en Suisse et à Moscou, Paris, Éditions de l'Atelier, 2001. There is also a more recent edited biographical dictionary of Cominternians in Latin America: Lazar Jeifets, Víctor Jeifets, Peter Huber, La Internacional Comunista y América Latina, 1919-1943. Diccionario biográfico, Moscow-Geneva, Institute of Latin America of the Russian Academy of Sciences, 2004.

7. Annie Kriegel and Stéphane Courtois, Eugen Fried. Le grand secret du PCF, Paris, Le Seuil, 1997; Lazar S. Kheifets, and Viktor L. Kheifets, 'Mikhail Borodin. The First Comintern-emissary to Latin America', The International Newsletter of Historical Studies on Comintern, Communism and Stalinism, 5-6 (1994-5), pp145-9 and 7-8; (1996), pp184-8; Dan N. Jacobs, Borodin: Stalin's Man in China, Cambridge, Mass, Harvard University Press, 1981.

8. Sophie Couré, La grande lueur à l'Est. Les Français et l'Union soviétique. 1917-1939, Paris, Le Seuil, 1999; Sabine Dullin, Des hommes d'influences: les ambassadeurs de Staline en Europe, Paris, Payot, 2001; Sophie Cœuré and Sabine Dullin (eds), Frontières du communisme. Mythologies et réalités de la division de l'Europe de la révolution d'octobre au mur de Berlin, Paris, Éditons La Découverte, 2007; Michael David-Fox, 'From "Illusory Society" to Intellectual "Public": VOKS, International Travel, and Party-Intelligentsia Relations in the Interwar Period', Contemporary European History (2002/1), pp7-32; Jean-François Fayet, VOKS. Le laboratoire helvétique. Histoire de la diplomatie culturelle soviétique de l'entre-deux-guerres, Geneva, Georg Éditeur, 2014; 'October, the Cold War and Commemoration: Solidarity at a Safe Distance?', Twentieth Century Communism, 13, 2017: October commemorations; Gianni Haver, Jean-François Fayet, Valérie Gorin and Emilia Koustova (eds), Le spectacle de la Révolution, Lausanne, Antipodes, 2017.

9. Silvio Pons, Stalin e la guerra inevitabile (1936-1941), Turin, Einaudi, 1995.

10. On this point see the debate surrounding the book by Silvio Pons, The Global Revolution (Oxford University Press, 2014) in Etienne ForestierPeyrat, Lisa Kirschenbaum, Silvio Pons, 'Débat autour d'un livre', in Monde(s). Histoire, espaces, relations, 10, 2016, pp167-83.

\footnotetext{
Twentieth Century Communism - Issue 14
} 
11. Erez Manela, The Wilsonian Moment. Self-determination and the International Origins of Anticolonial Nationalism, Oxford, Oxford University Press, 2007.

12. Terry Martin, The Affirmative Action Empire: Nations and Nationalism in the Soviet Union, 1923-1939, Ithaca, NY, Cornell University Press, 2001.

13. Ali Raza, Franziska Roy and Benjamin Zachariah (eds), The Internationalist Moment. South Asia, Worlds and World Views 1917-1939, Los Angeles, Cal, Sage, 2015, in particular Carolien Stolte, 'Uniting the Oppressed Peoples of the East: Revolutionary Internationalism in an Asian Inflection', pp56-85.

14. Marcel van der Linden, Workers of the World. Essays toward a Global Labor History, Leiden, Brill, 2008.

15. Madeleine Herren, Internationale Organisationen seit 1865. Eine Globalgeschichte der internationalen Ordnung, Darmstadt, Wissenschaftliche Buchgesellschaft, 2009; Martin H. Geyer and Johannes Paulmann (eds), The Mechanics of Internationalism. Culture, Society, and Politics from the 1840s to the First World War, Oxford, Oxford University Press, 2001.

16. Pierre-Yves Saunier, 'La secrétaire générale, l'ambassadeur et le docteur. Un conte en trois épisodes pour les historiens du "monde des causes" à l'époque contemporaine, 1800-2000', Monde(s). Histoire, espaces, relations, 1, 2012, pp29-46.

17. Josephine Fowler, Japanese and Chinese Immigrant Activists. Organizing in American and International Communist Movements, 1919-1933, New Brunswick, Rutgers University Press, 2007, esp. pp101-19; Holger Weiss, Framing a Radical African Atlantic: African American Agency, West African Intellectuals and the International Trade Union Committee of Negro Workers, Leiden, Brill, 2014. On the institutional history of the Profintern, the key work is Reiner Tosstorff, The Red International of Labour Unions (RILU) 1920-1937, Leiden, Brill, 2016.

18. Constance Margain, 'L'internationale des gens de la mer (1930-1937). Activités, parcours militants et résistance au nazisme d'un syndicat communiste de marins et de dockers', PhD thesis, Le Havre, 2015; Constance Margain, 'The International Union of Seamen and Harbour Workers (ISH) 1930-1937: Interclubs and Transnational Aspects', Twentieth Century Communism, 8, 2015, pp133-144. 
19. Alf Lüdtke (ed), Alltagsgeschichte. Zur Rekonstruktion historischer Erfahrungen und Lebensweisen, Frankfurt am Main, Campus, 1989; Belinda Davis, Thomas Lindenberger and Michael Wildt (eds), Alltag, Erfahrung, Eigensinn. Historisch-anthropologische Erkundungen, Frankfurt am Main, Campus, 2008. On Soviet history, see Sheila Fitzpatrick, Everyday Stalinism. Ordinary Life in Extraordinary Times: Soviet Russia in the 1930s, New York, Oxford University Press, 1999.

20. Claude Pennetier and Bernard Pudal, 'Écrire son autobiographie (Les autobiographies communistes d'institution, 1931-1939)', Genèses, 23, 1996, pp53-75; Pennetier and Pudal (eds), Autobiographies, autocritiques, aveux dans le monde communiste, Paris, Belin, 2002; Brigitte Studer, Berthold Unfried and Irène Herrmann (eds), Parler de soi sous Staline. La construction identitaire dans le communisme des années trente, Paris, Éditions de la Maison des sciences de l'homme, 2002. For self writing, see Michel Foucault, 'L'écriture de soi' in idem, Dits et écrits, vol. 4, Paris, Gallimard, 1983, pp415-30.

21. Reinhart Koselleck, Vergangene Zukunft. Zur Semantik geschichtlicher Zeiten, Frankfurt am Main, Suhrkamp, 1984.

22. Bert Hoppe, In Stalins Gefolgschaft. Moskau und die KPD 19281933, Munich, Oldenbourg, 2007; Gleb Albert, Das Charisma der Weltrevolution. Revolutionärer Internationalismus in der frühen Sowjetgesellschaft, 1917-1927, Cologne, Böhlau, 2017.

23. See the website https://www.muenzenbergforum.de (accessed June 2016).

24. Fredrick Petersson, Willi Münzenberg, the League against imperialism and the Comintern, 1925-1933, Lewiston, Queenston Press, 2 vols, 2013; Kasper Braskén, The International Workers' Relief, Communism, and Transnational Solidarity. Willi Münzenberg in Weimar Germany, Basingstoke, Palgrave Macmillan, 2015. For a bibliography see Bernhard H. Bayerlein et al, 'Research on Willi Münzenberg (1889-1940). Life, Activities, and Solidarity Networks. A Bibliography', INCS XVIII (2012/25), pp104-22, available at http://newsletter.icsap.de/home/data/ pdf/INCS_25_ONLINE.pdf. See also the (anti-communist-leaning) biography by Sean McMeekin, The Red Millionaire. A Political Biography of Willi Münzenberg, Moscow's Secret Propaganda Tsar in the West, New Haven, Yale University Press, 2003.

Twentieth Century Communism - Issue 14 
25. M.A. Kitaev, Oblastnye Biuro. Polnomochnye organy Tsentral'nogo Komiteta Partii, Moscow, Izdatel'stvo Politicheskoi Literatury, 1982; Étienne Peyrat, 'Retrouver le Caucase. Histoire d'une diplomatie frontalière (1905-1938)', PhD thesis, Sciences Po, Paris, December 2015.

26. 'Internationalisms in the Interwar Years: The Travelling of Ideas' in Raza, Internationalist Moment, pp1-21, esp. p4.

27. The study which brings together the largest amount of recent biographical data on Comintern activists remains that of Pierre Broué, Histoire de l'Internationale Communiste 1919-1943, Paris, Fayard, 1997.

28. A general survey has yet to be written, but among the numerous articles on the Comintern's cadre schools see Julia Köstenberger, 'Die Internationale Lenin-Schule (1926-1938)', in Michael Buckmiller, Klaus Meschkat (eds), Biographisches Handbuch zur Geschichte der Kommunistischen Internationale. Ein deutsch-russisches Forschungsprojekt, Berlin, Akademie Verlag, 2007, pp287-309; Woodford McClellan, 'Africans and Black Americans in the Comintern Schools, 19251934', International Journal of African Historical Studies (1993/2), pp371-390; Alexander V. Pantsov and Daria A. Spichak, 'New Light from the Russian Archives: Chinese Stalinists and Trotskyists at the International Lenin School in Moscow, 1926-1938', Twentieth Century China (2008/2), pp29-50.

29. Brigitte Studer, The Transnational World of the Cominternians, Basingstoke, Palgrave Macmillan, 2015.

30. Glennis Young, The Communist Experience in the Twentieth Century. A Global History through Sources, Oxford, Oxford University Press, 2012.

31. Thomas Sakmyster, A Communist Odyssey. The Life of József Pogány/John Pepper, Budapest, Central European University Press, 2012.

32. Patricia Albers, Shadows, Fire, Snow: The Life of Tina Modotti, Berkeley, Cal, University of California Press, 2002 edn; Ruth Price, The Lives of Agnes Smedley, Oxford, Oxford University Press, 2005; Mario Kessler, Ruth Fischer. Ein Leben mit und gegen Kommunisten (1895-1961), Vienna, Böhlau, 2013.

33. Erik S. McDuffie, Sojourning for Freedom: Black Women, American Communism, and the Making of Black Left Feminism, Durham, Duke University Press, 2011.

34. Sidney Tarrow, 'Rooted Cosmopolitans and Transnational Activists, 
in Sidney Tarrow (ed), Strangers at the Gates. Movements and States in Contentious Politics, Cambridge, Cambridge University Press, 2012, pp181-199.

35. For transcripts of speeches and resolutions see John Riddell (ed), To See the Dawn. Baku, 1920. First Congress of the Peoples of the East, New York, Pathfinder, 1993.

36. Cited Fowler, Japanese and Chinese Immigrant Activists, p101.

37. Claire Marynower, 'Réformer l'Algérie? Des militants socialistes en “situation coloniale” dans l'entre-deux-guerres', Histoire@Politique. Politique, culture, société, 13, 2011, pp112-24.

38. John Fisher, 'The Interdepartmental Committee on Eastern Unrest and British Responses to Bolshevik and other Intrigues Against the Empire during the 1920s', Journal of Asian History (2000/1), pp1-34.

39. Juri Tikhonow, 'Die Komintern und der "afghanische Korridor” 19191943', in Michael Buckmiller and Klaus Meschkat (eds), Biographisches Handbuch, op cit, pp314-316 (cf note 29); Sobhanala Datta Gupta, Comintern and the Destiny of Communism in India, 1919-1943: Dialectics of a real and possible History, Kolkotta, Seribaan, 2011 edn.

40. Céline Marangé, Le communisme vietnamien (1919-1991). Construction d'un État nation entre Moscou et Pékin, Paris, Presses de Sciences Po, 2012.

41. Kris Manjapra, 'Communist Internationalism and Transcolonial Recognition' in Sugata Bose and Kris Manjapra (eds), Cosmopolitan Thought Zones. South Asia and the Global Circulation of Idea, Basingstoke, Palgrave Macmillan, 2010, pp159-77, esp. p160.

42. Fowler, Japanese and Chinese Immigrant Activists, p101.

43. Robbie Aitken, 'From Cameroon to Germany and Back via Moscow and Paris. The Political Career of Joseph Bilé (1892-1959), Performer, "Negerarbeiter" and Comintern Activist (1892-1959)', Journal of Contemporary History (2008/4), pp597-616, esp. p603.

44. Hakim Adi, Pan-Africanism and Communism. The Communist International, Africa and the Diaspora, 1919-1939, Trenton, NJ, Africa World Press, 2013; Holger Weiss, Framing a Radical African Atlantic.

45. Michael Goebel, Anti-Imperial Metropolis. Interwar Paris and the Seeds of Third World Nationalism, Cambridge, Cambridge University Press, 2015; Jennifer Anne Boittin, Colonial Metropolis. The Urban Grounds of

Twentieth Century Communism - Issue 14 
Anti-Imperialism and Feminism in Interwar Paris, Lincoln, University of Nebraska Press, 2010.

46. Vijay Prashad, The Darker Nations. A People's History of the Third World (New York, New Press, 2007); for further references see note 25 above.

47. Gleb J. Albert, 'To help the Republicans not Just by Donations and Rallies, but with the Rifle: Militant Solidarity with the Spanish Republic in the Soviet Union, 1936-1937', European Review of HistoryRevue européenne d'histoire (2014/4), pp501-18.

48. Lawrence Hokkanen, Sylvia Hokkanen and Anita Middleton, Karelia: A Finnish-American Couple in Stalin's Russia, St. Cloud, Minn, North Star, 1991; Michael Gelb, 'Karelian Fever: The Finnish Immigrant Community During Stalin's Purges', Europe-Asia Studies (1993/6), pp1091-1116; Robert Weinberg, Stalin's Forgotten Zion: Birobidzhan and the Making of a Soviet Jewish Homeland: An Illustrated History, 19281996, Berkeley, Cal, University of California, 1998.

49. Lisa A. Kirschenbaum, International Communism and the Spanish Civil War: Solidarity and Suspicion, New York, Cambridge University Press, 2015.

50. David Featherstone, 'Black internationalism, international communism and anti-fascist political trajectories: African American volunteers in the Spanish Civil War', Twentieth Century Communism, 7, 2014, pp9-40.

51. David Featherstone, Solidarity: Hidden Histories and Geographies of Internationalism, London, Zed Books, 2012; Holger Weiss (ed), International Communism and Transnational Solidarity. Radical Networks, Mass Movements and Global Politics, 1919-1939, Dordrecht, Brill, 2016.

52. Braskén, International Workers' Relief.

53. Frédéric Genevée, 'L'Association juridique internationale (1929-1940)', in José Gotovitch and Anne Morelli (eds), Les solidarités internationales: Histoire et perspectives, Tournay, Éditions Labor, 2003; Heinz-Jürgen Schneider, Erika Schwarz and Josef Schwarz, Die Rechtsanwälte der Roten Hilfe Deutschlands. Politische Strafverteidiger in der Weimarer Republik. Geschichte und Biografien, Bonn, Pahl-Rugenstein, 2002.

54. Moshik Temkin, The Sacco-Vanzetti Affair. America on Trial, New Haven, CT, Yale University Press, 2009; Susan D. Pennybacker, From Scottsboro to Munich. Race and Political Culture in 1930s Britain, Princeton, NJ, Princeton University Press, 2009; James A. Miller, 
Susan D. Pennybacker and Eve Rosenhaft, 'Mother Ada Wright and the International Campaign to Free the Scottsboro Boys, 1931-1934', American Historical Review (2001/2), pp387-430; Kevin Morgan, International Communism and the Cult of the Individual: Leaders, Tribunes and Martyrs under Lenin and Stalin, Basingstoke, Palgrave Macmillan, 2017; Frederick S. Litten, 'The Noulens Affair. Research Note', China Quarterly, 138, June 1994, pp492-512.

55. Michael Goebel, 'Geopolitics, Transnational Solidarity or Diaspora Nationalism? The Global Career of M.N. Roy, 1915-1930', European Review of History/Revue européenne d'histoire (2014/4), pp485-99.

56. For the 'Hands off China' campaign see Braskén, International Workers' Relief, pp141-60. Spurred on by Münzenberg, Yakov Bliokh made one of the first political documentary films to receive wide distribution, The Shanghai Document (USSR, 1928), see Thomas Tode, 'La contreinformation cinématographique. Quelques traits de lumière tirés de l'histoire du cinéma', online: http://eipcp.net/transversal/1003/tode/ fr (accessed June 2016). For 'Hands off Ethiopia' see Joseph Fronczak, 'Local People's Global Politics: A Transnational History of the Hands Off Ethiopia Movement of 1935', Diplomatic History (2015/2), pp24574, also Featherstone, Solidarity.

57. Sabine Dullin, La frontière épaisse. Aux origines des politiques soviétiques (1920-1940), Paris, Éditions de l'EHESS, 2014, esp. pp238-263; Studer, Transnational World, pp126-43.

58. Aleksandr Iu Vatlin, Komintern. Idei, resheniia, sud'by, Moscow, ROSSPEN, 2009; Grant M. Adibekov (ed), Politbiuro TsK RKP (b)-VKP (b) i Komintern, 1919-1943gg, Moscow, ROSSPEN, 2004.

59. Bernhard H. Bayerlein et al, Moscou-Paris-Berlin. Télégrammes chiffrés du Komintern (1939-1941), Paris, Tallandier, 2003.

60. On this training see the recollections of Wolfgang Leonhard, Die Revolution entläßt ihre Kinder, Cologne, Kiepenheuer \& Witsch, 1955.

61. Constantin Katsakioris, 'L'Union soviétique et les intellectuels africains. Internationalisme, panafricanisme et négritude pendant les années de la décolonisation, 1954-1964', Cahiers du monde russe, 2006, pp15-32; Constantin Katsakioris, 'Leçons soviétiques: la formation des étudiants africains et arabes en URSS pendant la Guerre froide', $\mathrm{PhDl}$ thesis, Paris, EHESS, Februrary 2015. 
62. Holger Weiss, Framing a Radical African Atlantic; Georges Padmore, Pan-Africanism or Communism? The Coming Struggle for Africa, London, Dennis Dobson, 1956.

63. Michele L. Louro, 'India and the League Against Imperialism: A Special "Blend" of Nationalism and Internationalism' in Raza, Internationalist Moment, pp22-55.

64. Carole Boyce Davies, Left of Karl Marx: The Political Life of Black Communist Claudia Jones, Durham, Duke University Press, 2008; McDuffie, Sojourning for Freedom. 